\title{
ON JEWISH PARTICIPATION \\ IN THE TARYBA IN 1918
}

\section{ŠARUNNAS LIEKIS \\ Brandeis University, Waltham, Mass. Open Society Fund - Lithuania}

Lithuanian historians have paid little attention to Jewish politics in inter-war Lithuania. The concept of a paternalistic 'golden age' still prevails among Lithuanian historians. They see the majority-minority paradigm in Lithuania in a positive light and deny any serious conflicts between the two groups. The view is apologetic, and its tradition seemingly stems from eighteenth-century discussions on religious toleration in the Polish-Lithuanian Commonwealth, which later entered popular Lithuanian polemics over the nature of the Lithuanian past and future via Romantic literature. The fact that Jewish politicians joined the Taryba (Council) seemed once more to confirm traditional tolerance and attractiveness of the Lithuanian statehood to its minorities.

The theme of the Jewish politicians entering into cooperation with the Taryba has its place in the traditional Zionist narrative, when dealing with the issue of Jewish Autonomy in Lithuania. In tilis historiography the political organization of the Jewish comm ' nities 'in exile' and their relative autonomy was seen as an alternative structural framework that preserved the Jewish people. The theme of autonomy is perhaps one of the few areas where Zionist historiography abandoned one of the elements of its ideology, which referred to the Jews in exile as powerless and aimed at negating the galut. The attitude could be summarized as following: the Lithuanian-Jewish rapprochement was beneficial for the Jews and for the newborn Lithuanian state. Jewish Personal Autonomy was a bid to obtain internal and international recognition for Lithuania. The Jews were the only international group which clearly favoured the achievement of international recognition for Lithuania. ${ }^{1}$

'Š. Liekis, Accommodating National Minorities in Lithuania: The Case of JewishAutonomy, 1918-1925. UMI Dissertation Services, Ann Arbor, Mich., 1998, 10. 
However, Lithuanian-Jewish cooperation in 1917-1918 was determined from the very beginning by geopolitical realities, subjective and contradictory ideas about the vision of the future Lithuanian state.

Between the autumn of 1916 and the spring of 1917, Germany attempted once again to force Russia into separate peace negotiations. The announcement of a Polish Kingdom with limited independence (5 November 1916), as well as new speculations on the statehood of Lithuania and Courland were designed to serve this purpose. Russia's failure to respond to these manoeuvres stimulated annexationist tendencies towards Ober-Ost in Germany. However, the February 1917 Revolution in Russia and the US entry into war in AprilMay 1917 forced Germany to abandon annexationist tactics and finally to turn towards the rhetoric of national self-determination. Selfdetermination did not exclude the German strategic interest in a larger 'ethnographic Lithuania', including Vilnius and the Grodno provinces as a second state, after Poland, to secure German strategic interests in the east. ${ }^{2}$ In view of the diverse population of the Ober-Ost, the Germans decided to place their wage on the Lithuanians and to help build 'ethnographic' Lithuania as a buffer quasi-state between the Russians and the Poles. This coincided with the wishes of the mainstream Lithuanian politicians who wanted to include parts of Vilnius and Grodno provinces sparsely inhabited by Lithuanians in their future state. ${ }^{3}$ These Lithuanian politicians considered the "ethnographic principle' to be the basis for their self-determination, while German authorities saw it as a means to control Lithuania and to free it from Polish influence.

Actually, mainstream Lithuanian politicians in their meetings and writings from the second part of the nineteenth century had renounced the historic tradition of the Grand Duchy of Lithuania and declared their intention to set up a new, ethnic, national Lithuanian state. They asserted, however, that the area populated by the Lithuanian-speaking people had been in the past much larger, and demanded all of it for their new state. They claimed neither historic nor ethnic Lithuanian territory, but something in-between. ${ }^{4}$ The main

${ }^{2}$ H. R. Lutz, Fall of the German Empire, 1914-1918. Vol.1. New York, $1969,465$.

${ }^{3} \mathrm{Z}$. Ivinskis, The attitudes of the Lithuanian politicians to the territorial question in Lithuania were excellently analyzed by Česlovas Laurinavičius, Lietuvos-Sovietu Rusijos taikos sutartis. Vilnius, 1992.

${ }^{4}$ As an example could serve the Resolutions of the Lithuanian Meeting in Voronezh, 16-19 November 1917 and the Resolutions of the Lithuanian Conference in Vilnius, 18-22 September 1917, etc. 
Lithuanian theoretician of this territorial settlement was Petras Klimas. His recommendations were crucial for decision making of the Lithuanian politicians. Klimas' book on the Lithuanian borders, published in Vilnius in 1917, sealed the concept of ethnographic Lithuania. ${ }^{5}$ In his memoirs, he rejoiced over the fact that the concept of a Lithuania with a majority of Lithuanians, not the historic concept or territory of the whole Ober-Ost, had triumphed among Lithuanian politicians: 'Founding Lithuania, Lithuanians have to decide, not the minorities. It (i.e., the ethnographic concept) is the greatest victory of that principle'. ${ }^{6}$ The views of the Lithuanian leaders, at that time, were best expressed in the discussion between Steponas Kairys (leader of the Social Democratic Party) and Antanas Smetona (later President of Lithuania and leader of the Lithuanian Nationalist Party). When Smetona was asked by Kairys about the possibility of including the territories of Grodno and Białystok in the future Lithuania, he said, It is true that it is better to have more. But not always...Such expansion is not needed today for us ... We must reinvent the principle of ethnic Lithuania' ${ }^{7}$

On 31 July 1917, it was decided by the Germans to set up in Lithuania 'a purely Lithuanian Trustee Council.' This Council was summoned by the Ober-Ost administration in Vilnius on 1 August 1917. Among the ' 22 Lithuanian men of confidence' was 'a PoleLithuanian,' an estate owner (Stanisław Narutowicz) the brother of the future president of Poland, Gabrieł Narutowicz; also several other estate owners who defined themselves as 'Lithuanians' ${ }^{8}$ The Council gave an explanation in its meeting why the Belorussians and the Jews had not been invited:

At first we cooperated with the Belorussians as we had initially agreed. But when it became evident that Lithuania 'ad to be created within its ethnographic borders, and that the Vilnius region is really an ethnographic Lithuanian area, then the negotiations lost their meaning. The Jews in addition, looked only after their own interests and wanted to join Russia, although they were different from Russians. The Jews thus had no interest in Lithuanian independence. Because of that, the Bureau did not have consultations with them. The Bureau generally took an attitude that only Lithuanians and their nationally conscious representatives have the right to build Lithuania

${ }^{5} \mathrm{P}$. Klimas, Lietuva, jos gyventojai ir sienos. Vilnius, 1917.

${ }^{6} \mathrm{P}$. Klimas, Dienoraštis. 1915 XII I-1919 I 19. Chicago, 1988, 178.

7 'Organizacijos Komiteto Lietuvių Suvažiavimui Sušaukti Susirinkimo Posėdžiai'. Lietuvos Valstybès Tarybos Protokolai 1917-1918. Vilnius, 1991, 45-46.

${ }^{8}$ Ibid., 31-32. 
in its ethnographic borders. However, the rights of the minorities had to be protected in the newly founded Lithuanian state. ${ }^{9}$

The Council organized a conference on Lithuania with German approval. It agreed that the participants of the planned conference should be 'honest, resolute, and intelligent Lithuanians of all classes and political opinions and had to be over twenty-five years of age.' Participation by non-Lithuanians was vetoed in accordance with Smetona's reasoning: 'It is not practical. In this case we would have to talk Russian. We will not have a school instead of a conference. We make politics; these people may not be sincere with us. It is only the start. We can not let them in and invite others as well'. However, because of several objections, a compromise formula was reached: 'With the approval of the organizing committee, natives of Lithuania, not yet proficient in the Lithuanian language, but having proven by their activities their concern for the good of our nation and our land, can be also designated members of the conference'. ${ }^{10}$

The potential candidates for the extended conference were selected by the 'men of confidence'. Its members and delegates were provided with official permits to travel across the country to the conference. At the beginning of September, permission was granted to publish the political position of the 'men of confidence'. On 6 September 1917, the first issue of Lietuvos Aidas (Lithuanian Echo) appeared in Vilnius. At the same time, the Ober-Ost granted 300,000 marks to the Lithuanian committee.

The organization of the Conference was strongly opposed in Vilnius by the United Polish Parties, the Socialist groups and parties of the Poles, Belorussians, and Jews. They protested principally against the granting of supreme national representation only to the Lithuanians and of attempts to split the country into two parts: Lithuanian and non-Lithuanian. ${ }^{11}$

Some 264 representatives received invitations to participate in the conference. Of these, 222 participated in the conference in Vilnius on 18-22 September 1917. The discussion concerning national minorities in the future Lithuanian state took place on 21 September. In the discussion the participants were Andrius Domaševičius, Pranas Eidukevičius, Stanisław Narutowicz, Antanas Smetona and several others. ${ }^{12}$ The main issue in the discussion was how to guaran-

9'Ibid., 38.

${ }^{10}$ Ibid., 62.

${ }^{11}$ W. Sukiennicki, East Central Europe during World War I. Vol.1, New York, 1984, 372-373.

${ }^{12}$ Lietuvos Valstybès Tarybos Protokolai, 74-76. 
tee the rights of the national minorities. Some, like Domaševičius, even asked the conference to provide national autonomy for the minorities. However, nobody at this stage talked about its implementation. The general political declaration accepted at the conference was put in the following words:

1. For the free development of Lithuania, its evolution into an independent, democratically organized state, it is necessary within the ethnic borders of Lithuania, with some corrections for the expansion of economic life that the national minorities in Lithuania be guaranteed the conditions for their cultural development. In order to establish the ultimate foundations of independent Lithuania and her relations with neighboring states, a Constituent Assembly of Lithuania should be summoned in Vilnius and elected democratically by all the inhabitants.

2. Should the German Empire agree to proclaim a Lithuanian state before the Peace Conference, and to take on itself the defence of Lithuanian interests at the Conference, then the Lithuanian conference, taking into consideration the fact that, in normal conditions of peace, Lithuanian interests are directed toward the west much more than toward the east or south, accepts the possibility that the future Lithuanian state, without endangering its independent development, should enter into, as yet undetermined relations with the German Empire. ${ }^{13}$

For the transition of power from Germans to Lithuanians, the Conference also had elected a twenty-person Taryba. The Tcryba had the right to appoint new members with full rights, in numbers not exceeding the total membership. It was agreed that there should be from five to six representatives of the national minorities (Belorussians, Poles and Jews). In principle, they would be appointed, but the elections by the minorities themselves would be considered as definitive. However, representatives of the minorities in the Taryba had to agree with the resolution in favor of Lithuanian independence. They were not take part in any anti-Lithuanian activities and needed to know Lithuanian. ${ }^{14}$

\section{Jewish Politics and the Taryba}

The promise to enlarge the Taryba did not satisfy the majority of the politically active Poles, Belorussians and Jews. They opposed the Taryba on both legal and political grounds. The United Polish Parties in Lithuania and the Belorussian representatives of the different

${ }^{13}$ Ibid., 76.

${ }^{14}$ Ibid., 118-119. 
parties protested against the decisions taken by the Taryba. The Jews also strongly expressed their dissatisfaction. A resolution was accepted during a meeting of all-Jewish parties and organizations on 29 October $1917 .{ }^{15}$ The meeting approved a resolution which clearly expressed the views of the Jewish politicians as well as popular demands of the 'Jewish street':

We, representatives of all Jewish cultural, economic and charity organizations, and political and social movements of Vilnius, because of the possible enlargement of the Lithuanian Taryba by appointing to it Jewish, Belorussian and Polish representatives, after detailed discussion, have decided:

1) The Lithuanian Taryba is not elected by universal suffrage, but only by the representatives of the Lithuanian conference which to ok place in Vilnius on 18-22 September, and also exclusively by the residents of Lithuanian nationality;

2) The territory put under control of the Lithuanian Taryba is artificially separated from a large part of land, for example, Verwaltungsgebiet Bialystok-Grodno, which from an economic and a political standpoint is bound to Lithuania, but will now be left outside of it.

Thus, the Lithuanian Taryba may be recognized only as a legitimate representative of the Lithuanian people.

We are convinced that only statesmen, freely elected from all nationalities of Lithuania, can initiate real self-rule and can eliminate the misfortunes in our land and the poverty of people.

The resolution of the Jewish conference, authorized by the Militärverwaltung Lithuania and the Grodno-Bialystok areas is the only way by which Lithuanian Jews may participate in the Taryba. ${ }^{16}$

The resolution was handed to the member of the Taryba, Jonas Vileišis by a delegation consisting of Simon Rosenbaum, Rabbi Isaac Rubinstein and Cemach Szabad.

Indeed, though requesting recognition of a free Lithuanian state and intending to accept certain obligations on behalf of it, the Taryba had become a national and not a territorial representative body. The desire of the Germans and Lithuanians to legalize Taryba's authority prompted them to encourage the participation in the Taryba of the Belorussians, Jews and Poles. The United Polish Parties in Vilnius, hoping to bring Lithuania into some form of union with Poland, resolved socially to ostracize any Pole who accepted Taryba

${ }^{15}$ Leftists: United Socialists, Bundists, People's Union, Democrats, Bundists; Zionists and Poalei Zion; Orthodox Tseirei Zion and Shomre Tora.

${ }^{16}$ Resolution. LMAB RS, f.255-1019, 6. 
membership. ${ }^{17}$ The Taryba thus had to take action to undermine its isolation from the non-Lithuanians in Vilnius, above all the Jews. Another important reason for that was a wish not to allow the Poles to make an alliance of the non-Lithuanians in Vilnius and its surroundings for pro-Polish political advantages. However, the Polish United Parties overconfident, because of the Polish numerical majority in Vilnius, did not show an interest in drawing the Jews into their sphere of influence. The Jews, keeping in mind the difficult relationship between the Polska Partia Socialistyczna and Bund, between the PolishEndecja (the leading force among the Vilnius Poles) and all Jewish politicians in the past, were not keen to cooperate. The Polish United Parties and their politicians perceived all Vilnius Jews as a pro-Russian force and had identified them with the Jewish political left. Only a small unimportant faction of Jews, the Jewish intellectuals, was seen as willing to join Lithuania. ${ }^{18}$ However, the Polish rejection of Jewish cooperation made the task of forming a Jewish-Lithuanian alliance much easier. The idea of a possible Jewish-Lithuanian cooperation was advocated in nearly all Jewish newspapers published in Germany as well as in Lithuania. ${ }^{19}$ The internal strife in the Jewish community also helped the Taryba to achieve their goal. Two major Jewish political camps - the Zionists on the one hand and the Bundists on the other - were competing for the allegiance of the Jewish population. Both camps had equal influence in the Vilnius Jewish population in the years 1917-1918. For example, the elections to the Vilnius Kehillah on 24-26 Decemter 1918 demonstrated that 15,187 voters ( 30 per cent of all eligible voters who participated in the elections) distributed their preferences almost equally to both camps. The Zionists received $2+$ plus three seats of Poalei-Zion and the Bundists got 23 seats. The remaining 30 were divided as follows: Traders - 1, United Socialists - 3, People's Union - $10,{ }^{20}$ Democrats - 5, Tseirei-Israel - 2, Schomre-Tora - 2, the Jewish Artisans - 7. ${ }^{21}$

${ }^{17} \mathrm{~W}$. Sukiennicki, East-Central Europe, 516. The purpose of the Polish SelfDefence units in Vilnius was 'the defence of the Poles in these lands and incorporation of these areas into Poland,' see, G. Lukomski, \& R. E. Stolarski, Walka o Wilno. Z dziejów samoobrony Litwy i Bialorusi 1918-1919. Warszawa, 1994, 16.

${ }^{18}$ M.P. O Przyszłości Miasta Wilna i Guberniji Wileńskiej. Wilno, 1918, 6.

${ }^{19}$ Wilna, die Judische Stadt, Judische Rundschau, 9/23/1915; Z. Reizin, Idn in Lite. Lezte Nayes, Nr. 9, 3/25/1918.

${ }^{20}$ It represented Jewish Communal Establishment and communal leadership.

${ }^{21}$ Telegram vom 27.Dezember 1918, Central Zionist Archive in Jerusalem, Israel (henceforth CZA), Z3/132. 
The Bund was opposed to cooperate with forces representing 'capitalist interests'. The party hoped, with assistance of the proletarians from Germany and Russia, to establish Socialism and from the beginning of 1918, it joined with other leftist parties, mainly Communist, to found a workers' Socialist government. The Bundists actively took part in the Vilnius conference of leftist parties on 10 November 1918. After its collapse, because of major differences between the parties, the Bund actively participated in the organization of elections to the Vilnius Workers' Soviet, a body representing a wide coalition of leftist forces. As a result of the elections, the Bund got 60 seats, out of the total of 202 seats, while the Communists received 93. The Vilnius Workers' Soviet declared its authority in Vilnius and as a proponent of Soviet power in Lithuania on 15 December 1918, thus becoming the driving and legitimizing force for the implementation of Soviet power in Lithuania. The clandestine Soviet government in Lithuania was formed by Communists in Vilnius on 8 December 1918 under the leadership of Vincas Kapsukas and was supported by the Russian Bolsheviks. ${ }^{22}$ Thus Vilnius became the focus of a competition between the Lithuanian Taryba and the government of Kapsukas after the peace of Brest-Litovsk. One group was supported by the German authorities and the other by Soviet Russia. The third player in this complicated situation was the Polish committee and its Samoobrona (Self-Defence), which thought Vilnius to be a Polish city and had hopes of exploiting its numerical superiority to defeat both of the competitors.

\section{Building an Alliance}

A decision was made to satisfy the Presidium of the Taryba (Antanas Smetona, Steponas Kairys, Vladas Mironas, Jurgis Šaulys, Petras Klimas, and Aleksandras Stulginskis) by making contacts with representatives of the national minorities during the first meeting of the Lithuanian Taryba on 24 September $1917 .{ }^{23}$ The Taryba in its meeting on 17 October decided that the minority representatives should be elected at their conferences. If they did not succeed in settling issues at the conference, they might to be allowed to join the Taryba by direct negotiations. If these negotiations did not succeed, further

${ }^{2}$ It was made of Zigmas Angarietis, Pranas Svotelis-Proletaras, Aleksandras Jakševičius, Kazimierz Cichowski, Konstantin Kernowicz, Aizik Vainstein and Semion Dimanstein (together with the Chairman Vincas Kapsukas - four Lithuanians, two Poles and two Jews).

${ }^{23}$ Protokolas Nr.2, Lietuvos Valstybess Tarybos Protokolai, 132. 
negotiations would be canceled. ${ }^{24}$ When the members of the Taryba visited Berlin on 1 December 1917, they issued a political statement which, among other things, said: 'Den Nationalen Minoritaeten Litauens muessen ihren kulturellen Beduerfnissen zusagende Verhaeltnisse gesichert werden' (The national minorities should be guaranteed the conditions, allowing them to satisfy their own cultural demands). ${ }^{25}$

An anonymous letter to Lieutenant Hermann Struck, an officer of the Fifth Department in the administration of Ober-Ost, suggested that Simon Rosenbaum, the leader of the Lithuanian Zionists, had negotiated with unknown Taryba members in February 1918. The author of the letter to Struck insisted that Rosenbaum stressed the need to call a Jewish conference in order to send representatives to the Taryba. ${ }^{26}$

On 18 March 1918 the Taryba selected a committee (Steponas Kairys, Aleksandras Stulginskis and Jonas Vileišis) to negotiate with those Jewish and Belorussian representatives who according to the minutes of the meeting had made a suggestion earlier, to reach an agreement with the Taryba. ${ }^{27}$ The initiative came from the Zionists and from the so-called Volksfereinigung, representing the Vilnius Jewish establishment. The Zionists and the Volksfereinigung, which was made up mainly of former Russian Kadets, were frightened by the rapid radicalization of the Vilnius Jewish community and feared isolation in the face of the right-left split in the community, as well as in the face of the greater politicization growing along ethnic lines. The triangle consisting of Lithuanians, Poles and followers of Soviet authority did not offer them much. The Jewish left was aligning itself with the strengthening pro-Soviet forces, while the Poles did not show signs of cooperation and for the moment did not even seem to be participants in the politics of Vilnius. Thus, the Lithuanian suggestion to enter the Taryba seemed a godsend. Joining the Taryba would overcome their isolation and allow them to get into Ober-Ost politics. However their path to joining the Taryba was difficult and controversial.

In 1918 the most influential Vilnius Jewish newspaper Letzte Nayes came under the control of the Vilnius Zionists. ${ }^{28}$ The articles published there were favourable to a Jewish-Belorussian-Lithuanian

\footnotetext{
${ }^{24}$ Protokolas Nr.12, ibid., 142.

${ }^{25}$ Prie protokolo Nr.14, ibid, 144.

${ }^{26}$ Letter to H. Struck, February 1918, CZA Z3/132.

${ }^{27}$ Protokolas Nr.69, Lietuvos Valstybès Tarybos protokolai, 226.

${ }^{28} \mathrm{~S}$. Rosenbaum, Die Lage des Zionismus in Litauen, CZA Z3/131.
} 
alliance. However, they envisioned the political structure of a 'Greater Lithuania', including all lands of the former Grand Duchy of Lithuania, with some form of autonomy. ${ }^{29}$ Similar articles were published even in Poland. Urija Kazenelenbogen, with great sympathy for Jewish-Lithuanian cooperation, had sent a memorandum to the Taryba, entitled: 'Lithuanians and Jews.' He wrote, 'The present war is one in a series of Lithuanian wars with the neighbouring Polish, Prussian, and Russian nations. And if Lithuanians wanted to avoid being overwhelmed by waves of surrounding fierce neighbours... Here is needed, a natural union possibly lasting through the ages, though not yet solidified, of Jews and Lithuanians' ${ }^{30}$ Dr Arthur Handtke, desk officer at the Zionist Central Bureau in Berlin, was also overwhelmingly optimistic about possible future Jewish-Lithuanian cooperation, and saw it, after his visit to Vilnius, as mutually beneficial. According to him, the appearance of the Taryba on the political scene was a 'turning point in the political development of the country'. ${ }^{31}$

The Zionists of Vilnius were in close contact with the Central Zionist Office in Berlin. In February 1918 it founded an umbrella organization for the coordination of its activities in Eastern Europe. ${ }^{32}$ The desk officers, Dr Arthur Handtke and Dr Paul Nathan, were most active in helping to coordinate the decisions of the Lithuanian Zionists with those of the other wider German Jewish political groups.

Its first meeting discussed, among other matters, the economy and issues of Jewish-Lithuanian cooperation with the emissaries of the Lithuanian Zionists. This meeting took place on 6 February 1918. The Jewish Lithuanian side was represented by the Chief Rabbi of Vilnius Isaac Rubinstein and Rabbi of Kaunas Israel Nisan Krak. The Lithuanian Taryba, in the meeting minutes, was described as a body representing only Lithuanians and not caring about other nationalities. Nevertheless, the Taryba promised to provide national autonomy for the Jews. But at this time the Jews could not join the Taryba until after the Belorussians had joined. The Belorussians made up the majority of the population in the Vilnius area and not coordinating Jewish actions with them would endanger the Jews. ${ }^{33}$

The international climate had started to change by the middle of February 1918, thus diminishing any chances of an agreement

${ }^{29}$ Lezte Nayes, 11-12/ 1917 and the beginning of the 1918.

${ }^{30}$ Żydzi a Litwa, Dziennik Polski, Nr. 256, 8/11/1917.

${ }^{31}$ Dr A. Hantke to Verwaltung Ober-Ost, Abt.5, 26/10/1917, CZA Z3/131.

${ }^{32}$ J. Reinharz, Dokumente zur Geschichte des Deutschen Zionismus 1882

1933. Tübingen, 1981, 217.

${ }^{33}$ Protokol über eine Sitzung am Mittwoch, den 6. Februar 1918, Z3/132. 
with the Taryba. The Brest accords pushed Great Russia back to her 'natural' borders. The Brest negotiations were broken off on 10 February 1918, with the Lithuanian declaration of independence still officially unpublished. On 16 February 1918, all twenty original members of the Taryba gathered and resolved unanimously to publish the declaration of Lithuania's independence. The omission of references to the special conventions with Germany was resented by the Germans. However, it received recognition from Germany on 23 March 1918. The conditional recognition of Lithuania's freedom and independence in 'everlasting and firm union' with Germany was considered by the Taryba a great achievement. Nevertheless, slightly reorganized at the end of 1917, the Ober-Ost administration was left unchanged after the conclusion of peace in the east and the official recognition of Courland's and Lithuanian's independence. The relations between the Taryba and the Ober-Ost administration were rather tense. Despite its patronage in the Reichstag, the Taryba's attempts to intervene for the sake of the population were ignored, as well as its requests to be admitted into any practical work of administration. The negotiations about national minorities entering the powerless Taryba could not succeed because there were neither the political nor the practical incentives for the Jews and the Belorussians to be given that entrance.

On 8 April 1918, the Taryba's commission for negotiating with the national minorities sent invitations to Rabbi Isaac Rubinstein, Dr George Romm, Dr Simon Rosenbaum and others. The mediator for the Lithuanian Taryba was Romm, although it seems that Rosenbaum, a Zionist leader, was also involved in arranging the meeting. ${ }^{34}$ The text of the meeting minutes of 9 April 1918, because of its importance, is presented in full:

The meeting between the Taryba's commission made up of Jonas Vileišis, Steponas Kairys, Aleksandras Stulginskis and Jokūbas Šernas, and the representatives of the 'Jewish population', Dr Elijah Romm, Dr Simon Rosenbaum and Dr Cemach Szabad took place at the headquarters of the Taryba at 11 St George in Vilnius. Rabbi Isaac Rubinstein did not attend because of his illness nor did the representative of Bund ${ }^{35}$ because of its objections to the very idea of the meeting. The subject of the discussion was the possible entrance of Jewish representatives into the Taryba.

Romm, Rosenbaum, and Szabad made the following statement:

'1) They are not formal representatives of the Jewish population, but they express the opinions of well-known Jewish groups,

${ }^{34}$ Invitation, 8 April 1918, LMAB RS, f.255-1019, 2-2b.

${ }^{35}$ Josif Izbicki. 
namely, Szabad of the democratic groups, Rosenbaum - of the Zionists, and Romm for non-party Jewish members of the community.

2) The representatives (for the talks) would be elected only at the conference of the Jewish people. The request for the organization of such a conference has been given to the German authorities. We ask the Taryba to mediate in getting permission to call the conference'.

The members of the Taryba's commission have stated that the Lithuanian Taryba is prepared to mediate in getting permission for the calling of a Jewish Representatives' Conference. This Conference is to solve the problem of Jewish representation in the Taryba. According to the decision of the Lithuanian conference on 18-23 September 1917, the Taryba is to be enlarged by two Jewish representatives. Romm, Rosenbaum, and Szabad respond that the Jewish population recognizes an independent Lithuanian state and wants to participate in the real work of the Taryba. However, it finds that only two seats in the Taryba for the Jewish population do not correspond to the proportion of Jews in Lithuania. It was not acceptable to the Jews because the seat number for them had to be determined according to the proportion of Jews in Lithuania.

The members of the Taryba pointed out that the Lithuanian conference followed the principle of proportional representation. However, it had in mind only the territory from which the conference was called.

The representatives of the Jewish population pointed out that according to them, if the Jews were to be represented only from that territory then they should have one quarter of the seats in the Taryba. As a postscript, they added 'We, the Jews, confirming the content of these minutes, request mediation for the calling of the Jewish conference in general; we furthermore point out the real way to influence the Germans, namely, we suggest that the Taryba demand of the Reichskanzler the announcement of a conference because the Taryba in its present state represents the Lithuanian nationality alone. In order to have representation from the whole country, it has to be enlarged with representatives of all other nationalities, according to the principle of proportional representation' ${ }^{36}$

Rosenbaum sent a letter to Dr Paul Nathan informing him of the results of the talks with the Taryba. In his letter, he described the course of the negotiations including the position of the Belorussians and their attitude towards the Taryb $a .^{37}$ The fear of the Jewish com-

\footnotetext{
${ }^{36}$ Protocol, 9 April 1918, LMAB RS, f. 255-1019, 3-4.

${ }^{37}$ Abschrift den 14, April 1918, CZA Z3/132.
} 
munal establishment (the majority of them were also the Zionists) alienating a part of the community also played a role in the failure of these negotiations together with the Belorussian factor. Belorussian negotiations with the Taryba in Vilnius at the same time took a similar course. One might wonder whether Jewish and Belorussian actions were to some extent coordinated.

The negotiations between the Taryba and the Vilnius Belorussian Rada took place on 23 April 1918. The Belorussians were represented by Anton Luckiewicz, Dominyk Siemaszka and Jan Stankiewicz. Their demands were the following: 1) The Belorussians must be represented in the Taryba proportionally, approximately 25 per cent; 2 ) The territories of Białystok and Bielsk, inhabited by the Belorussians, must be attached to the projected Lithuanian-Belorussian state, while the political aim of the Belorussians was the restoration of the Grand Duchy of Lithuania. The future Lithuanian-Belorussian state was to have two federated parts, Lithuanian and Belorussian. The Belorussian part of the state was to have cultural and administrative autonomy. ${ }^{38}$ These negotiations between the Taryba and the Vilnius Belorussian Rada also did not lead anywhere. The Belorussians simply did not need the Taryba at the moment.

When Minsk was captured by the Germans on 19 February 1918, the Minsk Belorussian Rada and the Vilnius Belorussian Rada, were united, though the Vilnius Rada had preserved its independence. The first session of the united body took place on 19 March 1918. It proclaimed Belorussian independence on March 25, 1918. However, the Germans kept their hands free, and organized their own military administration in the newly occupied territories. But in practical terms the situations of the Taryba and of the Minsk Belorussian Rada looked similar.

Dr Simon Rosenbaum and his followers could also allow themselves, like the Belorussians, to demonstrate their adherence to the principle of 'equal representation' in the 'murky waters of the OberOst politics.' The real contenders for the Vilnius Region at this time seemed to be the Lithuanians and the Belorussians. ${ }^{39}$ Who would win the competition or what kind of the federated state in place of the former Grand Duchy of Lithuania would emerge was unpredictable. The German recognition of Lithuanian Independence on 23 March 1918 seemed to lack consequences. Although Dr Paul

${ }^{38}$ Protocol, LCVA, f.1014, ap.1, b. 24, 1-2.

${ }^{39}$ The Belorussian national movement contended the Lithuanian rights to the Vilnius Region from its inception. 
Nathan tried in his letter to soften the posture of Dr Rosenbaum in the Vilnius Zionist preconditions to enter the Taryba, he did not succeed. ${ }^{40}$ The Lithuanian side had to wait for the further development of the situation.

The Taryba reacted rather simply to the results of the negotiations with the Jews and the Belorussians. Agreement between the Taryba and minorities did not seem at this stage not essential. The Taryba issued the following resolution on 18 April 1918:

The Taryba found after hearing the report of the commission that minorities do not need to have equal positions with us, in order for minorities' representatives to be able to participate in the work of the Taryba. The Taryba firmly stands behind the decisions of the conference and suggests membership on that basis. ${ }^{41}$

Nevertheless, the Lithuanian Taryba made efforts to influence the Zionist Central Bureau to compel the Lithuanian Zionist leadership to compromise on their demands and position. An interesting episode was reported by the co-workers of the Stockholm bureau of the Poalei-Zion Party, Chasanowitsch and Locker. The Stockholm bureau of Poalei-Zion was visited on 2 May 1918 by Dr Jonas Šliupas, the liberal leader of the Lithuanian American community, and the Lithuanian envoy to Sweden, Šeinius, on 2 May 1918. Both painted a generally optimistic picture of the future of Jewish life in Lithuania. Everything was presented in such a way as to suggest that it would cost Jewish culture and Jewish social advancement dearly were the Jews not to reach an agreement with the Taryba. When asked about the main obstacle to the Jews joining the Taryba, the demand for a larger representation of the Jews in the Taryba, Šliupas argued that the Jews, because of the large number of the refugees, made up only 7-8 per cent of the population of Lithuania (he was right, as was shown of the 1923 census). Thus, two seats would allow the Jews to be represented proportionally in the Taryba.42

The stalemate about the minorities entering the Taryba continued until November 1918. At that time the Zionists seemed to expect nothing from that Taryba. The meeting of all Jewish political groupings in Vilnius at the beginning of October rejected any plans to enter its. On 6 October 1918 Cemach Szabad, the Democrats' representative, sent the following statement to the Taryba: 'I have the honor to inform you at your request that the whole of Jewish society,

${ }^{40}$ Letter of S. Rosenbaum to P. Nathan, 6 May 1918, CZA Z3/133.

${ }^{41}$ 'Protokolas Nr.74', Lietuvos Valstybès Tarybos Protokolai 1917-1918.

Vilnius, 1991, 244.

${ }^{42}$ Abschrift, 6 Mai 1918,CZA Z3/133. 
after consulting all representatives of all political trends and opinions in Jewry, has decided not to participate in the Lithuanian Taryba in its present form...' ${ }^{43}$

This was an ill prepared and a poorly thought out action. The Ober-Ost military administration of the territories occupied in the east was much criticized by the Reichstag majority and was formally abolished in August 1918. Two separate administrations were set up, one for the Baltic lands, the second for Lithuania, although both were still subordinated to the military supreme command. These administrative reforms were seen as an important step towards the final regulation of the political situation in the Baltic. ${ }^{44}$ The new policy was intended to attach the new states in the east to Germany through bonds of friendship rather than subjection. The German revolution and speculations about the coming end of the war also hastened the administrative changes. The genuine representation of the local population was to be needed at the coming peace conference to support German interests there. A cabinet decree 'On the Appointment of a Civilian Administration in the Baltic [countries] and Lithuania', signed by the Kaiser on 3 November, put a formal end to the military administration in those areas. ${ }^{45}$ The coming revolution in Germany encouraged the Taryba to form the first Cabinet under the Prime Minister Augustinas Voldemaras. The question of the minorities in the Taryba to make it more representative was raised again. However, the majority of the Taryba's members, unwilling to negotiate, rebuffed the acceptance of any feasible solution. The most eloquent opponent was Petras Klimas: 'We stand for the task of founding a state of the Lithuanians, and we are ready to do our job even if all minorities boycott us'. ${ }^{46}$ 'We need a declaration that the Taryba wants to guarantee all minority rights they need... The minorities are always radical. We have too much practice in dealing with them. We cannot expect anything positive from them'. ${ }^{47}$

The armistice was signed between Germany and the Allies on 11 November 1918. Two days later the Brest Treaties were annulled by Russia, raising indignation and panic in the Taryba. Lithuania was becoming a power vacuum. It became evident that the German troops would soon leave the city. The German revolutionized army

\footnotetext{
${ }^{43}$ Letter, 6 October 1918, LMAB RS, f. 255-1019, 5.

${ }^{44}$ Sukiennicki, East-Central Europe, vol.2, 792.

${ }^{45}$ Sukiennicki, East-Central Europe, vol. 2, 814

${ }^{46}$ Protokolas Nr.104. Lietuvos Valstybès Tarybos Protokolai, 378.

${ }^{47}$ Ibid., 379
} 
started forming Soldatenraten, closely fraternizing with the leftists in the city and with a strong Polish Self-Defence element. The Bolshevik emissaries began organizing their local forces for a takeover. The Lithuanian Taryba, without mass support in the city, started losing ground. The support of at least some political groups in the Jewish and Belorussian communities was urgently needed. The Taryba discussed the programme of the first Cabinet of Augustinas Voldemaras on 15 November 1918. One of the main deficiencies of the programme, Jonas Vileišis pointed out, was the fact that 'we do not have representatives of the national minorities of Belorussians, Jews, Poles and others. Thus, it is difficult to speak about the support given by the whole country to the authorities.' He suggested the need to follow more flexible tactics:

We have to acknowledge from this podium two important things. One, the Taryba never wanted and does not want to suppress the national minorities. It always invited and issues an invitation today to work in a common effort of nation building. The second point, the national minorities have to reject the tactics which were followed under the occupation authorities and clearly to make a statement that they support the founding of a democratic Lithuanian state' ${ }^{48}$

The entrance of the national minorities into the Taryba was speeded by the events in Minsk. The Minsk Belorussian Rada was particularly handicapped by internal disputes and was split between the right and left. The conflict with the Vilnius Rada autonomists, supporting the union with Lithuania, also surfaced. The representatives of the Belorussian Socialist Hramada and the majority of the other leftist parties left the Minsk Belorussian Rada by the beginning of November 1918. It became evident that the Rada in Minsk, without any external support, would not hold together long against the Bolsheviks, after the collapse of Germany on 11 November 1918.

The Belorussian Rada in Vilnius, at that moment, once again switched its attention to the Lithuanian Taryba. The Rada hastily presented its conditions for joining the Taryba on 14 November 1918. The Vilnius Rada demanded: 1) the Belorussians should get 25 per cent of the seats in the Taryba;2) the Rada should have a right to the seat of one Minister in the Cabinet; 3 ) the Belorussian collegium and secretariat for coordinating Belorussian politics has to be established; 4) the territories inhabited by Belorussians must get a share of the budget proportional to the size of population. ${ }^{49}$ The demands were accepted by the Taryba, which urgently needed any possible

${ }^{48}$ J. Aničas, Jonas Vileišis 1872-1942. Vilnius, 1995, 209.

${ }^{49} \mathrm{U}$ Litauskuiu Tarybu u Vilne, 11/15/1918, LCVA, ap. 2, b. 2, 17. 
support. Nevertheless, the Belorussians started demanding even more: the territories of Białystok and Bielsk had to be incorporated into Lithuania; territorial autonomy for Belorussian lands; official status for the Belorussian lands as well as setting up an inspection office for the Belorussian schools. ${ }^{50}$ However, the Taryba refused to accept their new demands on the grounds that the territorial allegiance of Białystok and Bielsk would be solved at the Peace Conference, while the question of the Belorussian autonomy and the status of the Belorussian language would be defined by the new Lithuanian Seimas. ${ }^{51}$ The Belorussian Rada was compelled to submit to the Taryba's position in the absences other alternative. Six Belorussian members were brought into the Taryba on 27 November 1918. Three additional Belorussian representatives from the Grodno region were brought into the Taryba on 4 April 1919.52 The Vilnius Belorussian Rada proposed as its candidate Józef Voronko, the former deputychairman of the Minsk Rada, to fill the seat of Minister for Belorussian Affairs on the same day that the Belorussians were seated in the Taryba. ${ }^{53}$ On 3 December 1918 Minsk fell into Bolshevik hands. The members of the Minsk Belorussian Rada took a refuge in Vilnius and Grodno. Before that, on 1 December 1918, the Lithuanian cabinet decided to establish the Ministry for Belorussian Affairs, with Józef Voronko at its head.

With the collapse of Germany, the position of the Jewish political groups, mainly Zionists, opposed to the pro-Soviet leftists in Vilnius also began to deteriorate. The hopes of any Belorussian state including Vilnius started to vanish. The Entente, like the Germans, was unwilling to consider Belorussian statehood. On 5 November 1918, the American representative in Copenhagen, Grant Smith, reported to the Secretary of State in Washington the details of a visit by Gregory Kaplan, representative of the Minsk Belorussian Rada, Stanislaw Khrzonstowski, mayor of Minsk, and Simon Rosenbaum, the leader of the Vilnius Zionists, who asked for military aid to Belorussia. The British refused. ${ }^{54}$ When the Belorussians entered

${ }^{50}$ U Radu Ministrou Litvy, 11/21/1918, LCVA, f. 582, ap. 2, b. 6, 18.

${ }^{51}$ Raštas Baltarusių Tarybai Vilnius, Nr.11, 11/26/1918, LCVA, f. 383, ap. 7 , b. 39,215 .

${ }^{52}$ The first six were W. Lastowski, I. Stakiewicz, I. Luckiewicz, D. Siemaszko, J. Falkewicz and V. Toloczka. J. Korczinski, K. Bielecki and the Minister for Belorussian Affairs J. Voronko were coopted on 4 April 1919. Lietuvos Valstybès Tarybos Nariai, LCVA, f. 1014, ap. 1, b. 20, 13-14.

${ }^{53} \mathrm{U}$ Radu Ministrou Litvy, 11/27/1918, LCVA, f. 582, ap. 2, b. 6, 19.

${ }^{54}$ FRUS (Foreign Relations US), Russia 1918. Vol.II, Washington, 1932, 844. 
the Taryba, the non-Socialist Jewish politicians were left in isolation. The choice had to be made between the Soviets and the Taryba. The Polish samoobrona was preparing for the military takeover of the city and did not need such allies. General Władysław Weytko, the commander of all forces in the Polish Self-Defense organization in Lithuania and Belorussia, pointed out in his memoirs that by midOctober, the total membership in the Polish Self-Defence organization in Vilnius amounted to 130 officers and 5,000 men. ${ }^{55}$ This was much higher than the number in all other groups. The Lithuanians had only about 100 armed men with the military headquarters and military intelligence office in Vilnius.

The Soviets and their Bundist allies in Vilnius, with their radical social rhetoric, were not acceptable to the Zionists and the Vilnius Jewish establishment for obvious reasons. The Taryba thus became an only choice.

Dr Ludwig Zimmerle, who was sent to Lithuania on 7 November 1918 as the German Commissar for the transitional period, was instrumental in setting up renewed contacts with the Taryba. Zimmerle held negotiations with Simon Rosenbaum on the question of the Zionists and their allies who were entering the Taryba. ${ }^{56}$ Rosenbaum's request to be allowed to make contacts and discuss issues with the Zionists of Lithuania was granted. The Zionist conference in Vilnius took place on 5-8 December 1918. There were 69 delegates from 33 towns and cities of Lithuania at the conference. Two important resolutions for Zionist politics and for the future Jewish-Lithuanian cooperation were adopted. The first resolution, entitled 'On the Political Situation,' raised the demand for personalnational autonomy and recognition of the Jewish nationality in all countries, which was important to the Zionist agenda. ${ }^{57}$ The conference issued the second declaration concerning the situation in Lithuania entitled 'Concerning Lithuania':

'1) The Congress welcomes the founding of the free Lithuanian democratic state based on the fundamentals of equality and national, personal self-rule of nations.

2) The present Taryba, as a governing body, is not elected on a democratic basis and is not a legitimate representation of the people.

${ }^{55}$ W. Weytko, Samoobrona Litwy i Białorusi. Szkic Historyczny. Wilno, 1930, 8; G. Lukomski, \& R. E. Stolarski, Walka o Wilno. Z dziejów Samoobrony Litwy $i$ Biatorusi. Warszawa, 1994, 19.

${ }^{56}$ Baricht des Herm Rechtsanwalt Rozenbaum aus Wilna über Litauen, CZA, Z3/131.

${ }^{57}$ Konferenz der Litauischen Zionisten, CZA, Z3/135; Die Beschlüsse der Zionisten-Konferenz in Wilna, LMAB RS, f. 79-730, 26-27. 
5) The Jewish candidates will participate in the Taryba under the following conditions:

a) The Taryba must share our view concerning the territory under their authority;

b) The Taryba states that it guarantees proportional representation to all nationalities of the country;

c) The Taryba states that it will not hinder the announcement Jewish conference in Lithuania, which will be an important body of our national-personal autonomy in Lithuania.

6) The Jewish candidates to the Taryba and to the provisional government must be elected by the Jewish Kehillot Conference. The Zionist Conference finds that it is not now possible, because at present they are not able to call such conference and because Jewish participation is urgent, to enter the Taryba on a needed interim basis...' 58

The Taryba discussed the question on the admitting of the Zionist candidates in its meeting on 11 December 1918. Personal national autonomy for the Jews of Lithuania was the main demand which was presented to the Taryba at the meeting. Three candidates were put up for consideration by the Taryba: Nachman Rachmilevich, Simon Rosenbaum, and Jacob Wygodski. The legitimacy of the candidates to represent the Jews was questioned by some members of the Taryba. The Zionist candidates were seen as representing a narrow section of the Jewish community. However, the majority of the Taryba's factions supported the admission of the candidates during the voting. ${ }^{59}$ The President of the Taryba, Antanas Smetona, delivered a speech on that occasion:

'When Lithuania is in danger, all its citizens have to come together in the organization of a renascent country, despite differences in their nationality and religion. The Taryba seeing the importance of such support, always took care to include among themselves not only Lithuanians, but also representatives of other nationalities of Lithuania. The Belorussians have recently sent their representatives. Today, we have here representatives of the Lithuanian Jews. This is a great event for founding and rebuilding Lithuania. The representation and the Government in democratic Lithuania must be

${ }^{58}$ Ibid.

${ }^{59}$ The motion was adopted by 17 votes to 2 . The Christian Democrats, Pažanga (The future Nationalist Party), the Belorussians and others voted yes. The Socialist Populists abstained, motivating it by a limited narrow political character of the representation. Žydu Kooptavimo Klausimu Lietuvos Taryboje, 12/11/1918, LMAB RS, f. 255-1089, 3-4; 6-8. 
built only on a democratic basis. The Lithuanians were the first to proclaim a declaration of independence. We see today that this declaration is not an empty claim. It is a weighty voice of the whole of Lithuania, which has been supported by the Belorussians, and today, we see, by the Jews. Lithuanians went along with the Jews in the Duma elections against the reactionary Russian government before the war and we are now fighting together against the reactionary forces in Lithuania as well.

The Jews have decided to join the Taryba and to participate in the provisional government, being convinced that nothing similar to the events in Warsaw, Cracow, and Lwow could happen. The Jews have full rights in our country, as do Lithuanians, Belorussians and other inhabitants of Lithuania.

I welcome the new Jewish members entering into our ranks in the name of the Taryba. I state that the Lithuanian groups, joined together in the Taryba, want to have a democratic Lithuania, where all nationalities and religions have equal rights. This wish will be implemented with all our energy. This is true for the entire Lithuanian nation. We hope that after the Jewish members have joined the Taryba, the work will go faster and the Provisional Government will have more support in the country. Welcome to our joint work. Long live the independent and democratic Lithuania. Long live our new coworkers'. ${ }^{60}$

All three Jewish politicians received positions in the Government. Simon Rosenbaum became the Deputy Minister of Foreign Affairs, Nachman Rachmilevich Deputy Minister of Trade and Industry, while Jacob Wygodski became the Minister for Jewish Affairs in the Government of Augustinas Voldemaras. The Taryba held a reception on behalf of the recently seated Jewish members in its headquarters on 12 December $1918 .{ }^{61}$ But the optimism soon turned into despair. The Russian Soviet Republic granted recognition on 22 December 1918 to the Lithuanian Soviet Republic, which had been proclaimed at the meeting of the Vilnius Soviet on 15 December. The Russians obliged all Russian institutions to provide help to the 'new proletarian state.' The Germans left Vilnius on 31 December 1918. The Taryba and the Voldemaras cabinet departed on 2 January 1919 on the last train to Kaunas since the Lithuanian army, still in an embryonic stage, was made up mainly of officers who could not re-

${ }^{60}$ Privetstvennaia Rech, Appendix. Lietuvos Valstybès Tarybos Protokolai, 463-464.

${ }^{61}$ Eintritt der Jüdischen Nation in die Litauische Taryba, CZA, Z3/135. 
sist the regular Soviet units. ${ }^{62}$ The Jewish members of the Taryba (except Jacob Wygodski who did not want to leave the city) also left for Kaunas.

The involvement of Jewish representatives in the Taryba opened a new page in the Lithuanian-Jewish cooperation. The Lithuanian state gained an additional argument for its legitimacy on the home front and internationally. The rapproachment made feasible further development of the Jewish Autonomy and its institutionalization in Lithuania.

However, the whole turn of events confirmed the fact that neither sympathies nor good will were the true determinants of alliance and cooperation in any political setting. Political interests visions and, most importantly, political realities and partnerships on the ground were the main factors making Lithuanian-Jewish Alliance work.

${ }^{62}$ The russified Belorussian general Cyprion Kondratowicz was appointed the commander of the Lithuanian Army at that stage. He actually was famous for his ignorance and low level skills as a military man and was soon dismissed. Kondratowicz, practically, did not make any great difference between Russia and Lithuania. At the beginning of his military career in the Lithuanian army he once asked an officer 'A razvie u vas prikazy po-litovski pišutsia?' (Rus. Are orders really written in Lithuanian in your command?). J. Petruitis, Laisvę Ginant. II tomas Stamford, 1953, 15. 